\title{
Short communication \\ Effects of fibre source on nutrient digestibility of diets for finishing lambs
}

\author{
J.F. Macdonald ${ }^{1}$, O.B. Einkamerer ${ }^{1 \#}$, A. Hugo ${ }^{2}$, A. Lepori ${ }^{1}$, G.C. Josling ${ }^{1}$ \& M.D. Fair ${ }^{1}$ \\ ${ }^{1}$ Department of Animal, Wildlife, and Grassland Sciences, P.O. Box 339, University of the Free State, Bloemfontein, \\ 9300 , South Africa \\ ${ }^{2}$ Department of Microbial, Biochemical and Food Biotechnology, P.O. Box 339, University of the Free State, \\ Bloemfontein, 9300, South Africa
}

(Received 10 July 2019; 2 November 2020; Published 21 January 2021)

\begin{abstract}
Copyright resides with the authors in terms of the Creative Commons Attribution 4.0 South African License.
See: http://creativecommons.org/licenses/by/4.0/za

Condition of use: The user may copy, distribute, transmit and adapt the work, but must recognize the authors and the South African Journal of Animal Science.
\end{abstract}

\begin{abstract}
Inexpensive fibre sources might be used as an alternative to lucerne hay in diets for finishing lambs. Thus, effects of providing fibre from lucerne hay $(\mathrm{LH})$, soyhulls $(\mathrm{SH})$, maize stover $(\mathrm{MS})$ and Eragrostis teff hay $(E T)$ on the nutrient digestibility of diets of finishing lambs with comparable NDF and nutrient concentration were evaluated. Thirty-six individually housed Merino ram lambs $(\bar{x}=43.03, \mathrm{SD}=3.72 \mathrm{~kg})$ were randomly allocated to four diets ( $\mathrm{n}=9$ lambs/treatment). A digestibility study was conducted to determine the nutrient availability of these diets. Dry matter (DM) intake of SH (1436 g) was lower than ET $(1716 \mathrm{~g})$. No differences were recorded between treatments for digestibility of NDF (0.32 - 0.34), acid detergent fibre (ADF) $(0.41-0.44)$, and ether extract (EE) $(0.67-0.75)$, except that MS (0.23) had lower NDF digestibility. Digestibility of DM, organic matter (OM) and non-structural carbohydrates (NSC) were similar for the LH $(0.72 ; 0.75 ; 0.96)$ and $\mathrm{SH}(0.70 ; 0.74 ; 0.95)$ diets, whereas digestibility of crude protein (CP) (0.71 vs. 0.68$)$, metabolizable energy (ME) (9.49 vs. $8.90 \mathrm{MJ} / \mathrm{kg} \mathrm{DM})$, and the available ash fraction ( 0.39 vs. 0.28$)$ were altered. The SH and $\mathrm{ET}(8.70 \mathrm{MJ} / \mathrm{kg} \mathrm{DM})$ treatments had similar ME concentrations, but ET had lower DM digestibility (0.68). The MS treatment had the lowest ME concentration (8.25 MJ/kg DM). The $\mathrm{LH}$ treatment resulted in overall better nutrient availability compared with $\mathrm{SH}, \mathrm{MS}$, and $\mathrm{ET}$.
\end{abstract}

Keywords: Eragrostis teff hay, lucerne hay, maize stover, nutrient availability, soybean hulls

${ }^{\#}$ Corresponding author: einkamererob@ufs.ac.za

Feeding high-concentrate diets to finishing lambs generally improves lamb performance (Jabbar \& Anjum, 2008; Shivambu et al., 2011). However, lamb feedlot diets require a minimum amount of fibre to ensure normal rumen functioning, which differs according to the chemical and physical properties of the fibre source (Jeon et al., 2019). Lucerne hay is usually the primary fibre source that is used in high-producing animals such as growing lambs, but it can be expensive and its quality varies. Furthermore, research is limited that compared the effect of fibre source on the nutrient availability of complete lamb finishing diets based on equivalent NDF concentration, especially those containing high levels of concentrate ( $>50 \%$ grain) (Flores-Mar et al., 2018). This lack of information hinders the use of less expensive alternative sources in lamb finishing diets. The cell wall concentration (NDF fraction) of fibre sources has the biggest single influence on DM intake and thus on energy intake among forages (McDonald et al., 2011; Tedeschi et al., 2019). Therefore, the aim of the study was to evaluate the effect of lucerne, soyhulls, Eragrostis teff hay, and maize stover on the nutrient digestibility of high-concentrate (55\% maize) finishing lamb diets with comparable NDF and nutrient concentration.

All procedures were approved by the Animal Ethics Committee for Animal Experimentation at the University of the Free State (Animal Experiment No. UFS-AED2018/0004). A digestibility study was conducted at Paradys Experimental Farm, University of the Free State, Bloemfontein, South Africa. Thirty-six Merino ram lambs were randomly allocated to four dietary treatments $(n=9$ lambs/treatment) from wean to slaughter. Lambs were housed in individual pens, and water was provided ad libitum. A $15 \%$ feed refusal level, based on the average feed intake of the preceding three days, was maintained to ensure that feed weighed out daily for each animal allowed for ad libitum and consistent feed intake. Four diets were 
formulated to be nutritionally comparable, but differed in fibre source, that is, lucerne hay (LH), soyhulls ( $\mathrm{SH}$ ), maize stover (MS) and Eragrostis teff hay (ET) (Table 1).

Table 1 Analysed chemical and physical composition of four dietary treatments that differed in fibre source

\begin{tabular}{|c|c|c|c|c|}
\hline \multirow{2}{*}{ Raw materials $(\mathrm{g} / \mathrm{kg})$} & \multicolumn{4}{|c|}{ Primary source of fibre in diet } \\
\hline & Lucerne hay & Soybean hulls & Eragrostis teff hay & Maize stover \\
\hline Maize meal & 550 & 550 & 550 & 550 \\
\hline Lucerne hay & 350 & & & \\
\hline Soyhulls & & 229 & & \\
\hline Maize stover & & & & 195 \\
\hline Eragrostis teff hay & & & 216 & \\
\hline Soybean oil & 0.3 & & 2.4 & 2.9 \\
\hline Citrus pulp & 69 & 177 & 179 & 201 \\
\hline Urea & 6.6 & 14.3 & 19.1 & 20.7 \\
\hline Limestone & 2.5 & 6.7 & 8.5 & 7.2 \\
\hline Ammonium chloride & 7.5 & 7.5 & 7.5 & 7.5 \\
\hline Mono-calcium phosphate & 7.0 & 8.5 & 9.2 & 8.5 \\
\hline Salt & 5.0 & 5.0 & 5.0 & 5.0 \\
\hline Mineral and vitamin premix ${ }^{1}$ & 2.5 & 2.5 & 2.5 & 2.5 \\
\hline \multicolumn{5}{|l|}{ Nutrient composition (g/kg DM) } \\
\hline Dry matter & 926 & 924 & 933 & 931 \\
\hline Organic matter & 923 & 916 & 906 & 908 \\
\hline Ash & 78 & 84 & 94 & 92 \\
\hline Crude protein & 153 & 156 & 154 & 151 \\
\hline Non-structural carbohydrates & 487 & 493 & 455 & 486 \\
\hline Neutral-detergent fibre & 245 & 232 & 265 & 240 \\
\hline Acid-detergent fibre & 176 & 197 & 181 & 189 \\
\hline Ether extract & 37 & 35 & 32 & 31 \\
\hline
\end{tabular}

${ }^{1}$ Vitamin A: $3500000 \mathrm{lU} /$ ton, vitamin B1: $2.0 \mathrm{~g} /$ ton, cobalt: $1.5 \mathrm{~g} / \mathrm{ton}$, ferrous iron: $30.0 \mathrm{~g} /$ ton, iodine: $1 \mathrm{~g} /$ ton, manganese: $30.0 \mathrm{~g} / \mathrm{ton}$, selenium: $0.3 \mathrm{~g} / \mathrm{ton}$, zinc: $65.0 \mathrm{~g} / \mathrm{ton}$, salinomycin: $18 \mathrm{mg} / \mathrm{ton}$, zinc bacitracin: $25.0 \mathrm{~g} / \mathrm{ton}$, Toxibind (Bitek Industries, Kempton Park, South Africa): $500.0 \mathrm{~g} / \mathrm{ton}$

It was essential to balance the treatments for dietary CP content because microbial protein synthesis is affected by the rumen concentration of nitrogen-containing compounds and organic matter fermentation (Soto-Navarro et al., 2003). The NRC (2007) nutrient requirements for finishing ram lambs were used as guidelines to formulate the experimental diets $(40 \mathrm{~kg}$ late maturing lambs growing at an average of 300 $\mathrm{g} /$ day). The diets were prepared with these fibre sources and citrus pulp in an attempt to equalize the NDF concentration of the treatments at approximately $245.5 \mathrm{~g} / \mathrm{kg}$ (Bampidis \& Robinson, 2006). The rationale for equalizing the NDF content of the diets was that it could affect animal voluntary DM intake, which is the major factor in energy intake (Decruyenaere et al., 2009). Likewise, soybean oil was used to balance the lipid content between treatments. Therefore, the focal point of this study was the possible effect of fibre quality on DM intake (Lopes et al., 2007) and available nutrient content (including energy) for the animal (Ball et al., 2001). A synthetic antioxidant was included in all diets to prevent fatty acid oxidation. The treatment diets were presented to the lambs in pelleted form ( $5 \mathrm{~mm}$ diameter) to avoid selective feeding. At four months old $(\bar{x}=43.03, S D=3.72 \mathrm{~kg}$ ) lambs entered a digestibility trial. The digestibility study was conducted over seven days after adaptation (seven days) to the faecal bags that were fitted to the animals. Lambs were fed twice daily ( $07 \mathrm{~h} 00$ and $16 \mathrm{~h} 00$ ), and feed refusals were collected every morning before feeding. Total faeces were collected, dried, and weighed. Daily feed, feed refusal and faecal samples of each animal were composited. After thorough mixing, representative samples were taken, ground to pass through a $1 \mathrm{~mm}$ 
sieve and stored pending chemical analyses. Milled feed, feed refusal and faecal samples were analysed for DM, CP, gross energy (GE), ash, NDF and ADF, and OM and NSC were calculated (AOAC, 2000; Van Soest et al., 1991). The ME concentration was calculated from digestible energy (DE) values by multiplying $\mathrm{DE}$ by a factor of 0.81 (McDonald et al., 2011) to compensate for energy losses in the urine and methane gas. Apparent digestible coefficients were calculated accordingly. Data were subjected to a Shapiro-Wilk test $(P \leq 0.01)$ to test for deviations from normality (Shapiro \& Wilk, 1965). Then, data were analysed with the one-way ANOVA procedure of SAS (SAS Institute Inc., Cary, North Carolina, USA) and Tukey's honest significant difference (HSD) test to identify significant differences between dietary treatments $(P<0.05)$.

Lambs had comparable DM intake between treatments with the exception of ET $(1716 \mathrm{~g})$, which had a higher $(P<0.05)$ DM intake than SH $(1436 \mathrm{~g})$. The DM digestibility coefficients of $\mathrm{LH}(0.72)$ and $\mathrm{SH}(0.70)$ were significantly higher than MS (0.66) and ET (0.68). For OM, digestibility ranged from 0.68 for MS to 0.74 for the $\mathrm{LH}$ treatment $(P<0.05)$. The availability of the ash fraction of $\mathrm{LH}(0.39)$ was significantly higher than the ET (0.29), MS (0.28) and SH (0.28) treatments. No differences were recorded between SH (0.68) and MS (0.68) for CP digestibility, but both were lower $(P<0.05)$ compared with LH $(0.71)$ and ET $(0.72)$. Digestibility of the NSC fraction was significantly higher for LH (0.96) and SH (0.95) compared with MS (0.92), whereas only LH differed $(P<0.05)$ from the ET $(0.95)$ treatment. No significant difference was detected between ET and MS. Overall, the lowest $(P<0.05)$ NDF digestibility coefficient $(0.23)$ was recorded for the MS treatment, with no notable differences between LH (0.34), ET (0.32) and SH (0.34). No significant differences were recorded between the treatment means for ADF and EE digestibility, which ranged from 0.41 to 0.44 and from 0.67 to 0.75 , respectively. Finally, the fibre sources were ranked $(P<0.05)$ based on the ME (MJ/kg DM) of the treatments: LH (9.49) > SH (8.90) and ET (8.70) > MS (8.25). The effects of fibre source on DM intake, apparent digestibility and ME concentration of diets fed to Merino lambs are presented in Table 2. Data of all traits in Table 2 followed a normal distribution.

Table 2 Effects of fibre source in finishing diets for lambs on dry matter intake, digestibility and metabolizable energy

\begin{tabular}{lcccccc}
\hline & \multicolumn{5}{c}{ Primary source of fibre in diet } & \\
\cline { 2 - 4 } & Lucerne hay & Soybean hulls & $\begin{array}{c}\text { Eragrostis } \\
\text { teff hay }\end{array}$ & Maize stover & $P$-value & SE \\
\hline Dry matter intake, g/day & $1604^{\mathrm{ab}}$ & $1436^{\mathrm{b}}$ & $1716^{\mathrm{a}}$ & $1694^{\mathrm{ab}}$ & 0.0360 & 35.49 \\
ME, MJ/kg DM & $9.49^{\mathrm{a}}$ & $8.90^{\mathrm{b}}$ & $8.70^{\mathrm{b}}$ & $8.25^{\mathrm{c}}$ & $<0.0001$ & 0.047 \\
Digestibility & & & & & & \\
Dry matter & $0.72^{\mathrm{a}}$ & $0.70^{\mathrm{a}}$ & $0.68^{\mathrm{b}}$ & $0.66^{\mathrm{b}}$ & $<0.0001$ & 0.003 \\
Organic matter & $0.75^{\mathrm{a}}$ & $0.74^{\mathrm{ab}}$ & $0.72^{\mathrm{b}}$ & $0.68^{\mathrm{c}}$ & $<0.0001$ & 0.004 \\
Ash & $0.39^{\mathrm{a}}$ & $0.28^{\mathrm{b}}$ & $0.29^{\mathrm{b}}$ & $0.28^{\mathrm{b}}$ & 0.0008 & 0.014 \\
Crude protein & $0.71^{\mathrm{a}}$ & $0.68^{\mathrm{b}}$ & $0.72^{\mathrm{a}}$ & $0.68^{\mathrm{b}}$ & $<0.0001$ & 0.003 \\
NSC & $0.96^{\mathrm{a}}$ & $0.95^{\mathrm{ab}}$ & $0.94^{\mathrm{bc}}$ & $0.92^{\mathrm{c}}$ & 0.0003 & 0.003 \\
Neutral-detergent fibre & $0.34^{\mathrm{a}}$ & $0.34^{\mathrm{a}}$ & $0.32^{\mathrm{a}}$ & $0.23^{\mathrm{b}}$ & 0.0002 & 0.009 \\
Acid-detergent fibre & 0.42 & 0.44 & 0.41 & 0.44 & 0.2948 & 0.008 \\
Ether extract & 0.75 & 0.71 & 0.72 & 0.67 & 0.4607 & 0.019
\end{tabular}

${ }^{a, b, c}$ Within a row, means with a common superscript were not different with probability $P=0.05$

ME: metabolizable energy, NSC: Non-structural carbohydrates

The dry matter intake of a fibre source can be influenced by factors such as NDF concentration, fill factor, rate of digestion and palatability (Ball et al., 2001; Decruyenaere et al., 2009). The cell wall concentration (NDF fraction) of fibre sources has the single biggest influence on DM intake ((Tedeschi et al., 2019). For this reason, these treatments were formulated to contain comparable levels of NDF (245.5 g/kg DM). However, NDF values ranged between $232 \mathrm{~g} / \mathrm{kg} \mathrm{DM}$ for SH and $265 \mathrm{~g} / \mathrm{kg} \mathrm{DM}$ for ET, effectively provoking a response in DM intake between these treatments. Lambs fed the ET diet compensated for the energy dilution effect of the higher cell wall concentration by increasing DM intake. Saylor et al. (2018) investigated the potential of replacing lucerne hay and maize silage in the diets of dairy cows with Eragrostis teff hay as the sole forage, and found no difference in DM intake or DM and NDF digestibility when diets 
were balanced for DM, CP and NDF concentration. The lower DM digestibility coefficient of ET compared with $\mathrm{LH}$ and $\mathrm{SH}$ could not be ascribed to differences in digestibility of the CP, NDF, ADF, and EE fractions, but to the variations in the dietary NDF to NSC ratio and partly to the availability of the mineral and NSC fractions. Besides the higher NDF level, the ET diet had the highest ash concentration, which contributed to the lower ME value compared with LH.

The results on the DM intake of lambs fed the SH diet were similar to those of Cunningham et al. (1993), who reported a decrease in DM intake when soybean hulls replaced forage of dairy cows, with no effect on the DM and OM digestibility, but altered protein digestion. Similarly, Araujo et al. (2008b) found that CP digestibility decreased when SH was included in lamb diets, but reported an increase in DM intake. Although the negative effect on CP digestibility was not large enough to elicit an overall response in DM and OM digestibility, it contributed to the lower ME value of the SH diet alongside the lower DM intake. Cunningham et al. (1993) ascribed the decrease in DM intake and CP digestibility to the decrease in particle size of SH compared with forage. Ipharraguerre and Clark (2003) reported that the inclusion of more than $300 \mathrm{~g} / \mathrm{kg}$ DM soybean hulls in high-grain diets $(\geq 50 \%)$ that lack long-length forage fibre may elevate the concentration of acids in the rumen, increase the ruminal passage rate (displacing fermentation of fibre from the rumen to the lower digestive tract) and decrease the DM intake of dairy cows. In contrast, Araujo et al. (2008a) replaced forage with SH (100\%) in diets of lactating ewes and found an increase in DM intake, milk production and lamb weaning weight. Sheep generally spend more time eating and ruminating than cattle, which makes them less prone to digestive disorders (Mulvenna et al., 2018). This brings into question the assumption that the same particle size limitations apply to cattle and sheep. However, there has been research into the replacement of forage fibre with non-forage fibre sources such $\mathrm{SH}$ in high-concentrate diets. Nevertheless, the current results indicated that there were negative associative effects in DM intake, $\mathrm{CP}$ digestibility and ME when soybean hulls were the sole fibre source in lamb diets containing $55 \%$ maize.

The collective lower digestibility of the NDF, NSC, CP, OM, and DM fractions of the MS treatment was typically related to the advanced maturity of the fibre source (Sun et al., 2017) and could not be overcome by positive associative effects of a complete diet, despite the increased concentrate to roughage ratio. Maize stover is a by-product of a physiologically mature maize plant, which is associated with an increase in stemto-leaf ratio, lignin content and lignification (Moore \& Jung, 2001). Lignin covers the cellulose microfibrils and binds chemically to hemicellulose (in NDF fraction) and pectin (in NSC fraction). This binding negatively affects the digestibility of hemicelluloses and pectin to a greater extent than cellulose (Dryden, 2008). It explains the lower NDF and NSC digestibility of MS in the present study with no associated differences in ADF concentration and ADF digestibility compared with the other fibre sources. The current results agree with those of Harper and McNeill (2015), who reported that lignification has a greater influence on the digestibility of a mature fibre source than lignin content. Furthermore, when one considers the small contribution of maize stover to the total CP content of the MS diet, the lower ME could have contributed to the lower CP digestibility by limiting the efficiency of nitrogen capture from non-protein nitrogen (urea). In comparison, the CP digestibility of the ET diet with a similar urea inclusion level was not affected in the same way because of its higher ME concentration. The lower ME of the MS treatment was therefore ascribed largely to the inferior digestibility of the carbohydrate (NDF and NSC) fractions, which affected the digestibility of $\mathrm{CP}, \mathrm{OM}$, and $\mathrm{DM}$, whereas the elevated ash concentration also contributed to the overall lower ME concentration. The results of the present study are in contrast to the results of Flores-Mar et al. (2018), who found that sorghum stover was superior to lucerne hay as a fibre source in lamb feedlot diet. However, the dietary NDF levels (maximum $90 \mathrm{~g} / \mathrm{kg}$ ) in their study were markedly lower than the present study.

Dry matter intake in the present study was comparable between the lucerne-based diet and other fibre sources. Poore et al. (1991), Cherney et al. (2004), and Flores-Mar et al. (2018) also observed no differences in the DM intake of dairy cows and growing lambs whether lucerne, wheat straw, orchard grass, tall fescue, or sorghum stover served as the source of fibre when dietary NDF was constant in the range of 60 to $300 \mathrm{~g} / \mathrm{kg}$ DM. However, the absence of a positive response in voluntary DM intake with rapidly digestible fibre indicates that ruminal fill is not the main limiting factor of intake (Jung \& Allen, 1995). Legumes are more susceptible to particle breakdown grasses when ground mechanically and pelleted (Paulson et al., 2008), which might have resulted in the lack of physical fill of the LH and SH treatments in the present study. Although the higher ME value of $\mathrm{LH}$ compared with $\mathrm{SH}, \mathrm{MS}$ and ET was ascribed partly to higher OM concentration, the better availability of the CP and NSC fractions played a role in improving OM digestibility, resulting in overall higher energy concentration of the LH diet. These results agree with those of Martin and Mertens (2005) and Scholtz (2009), who ascribed the advantage of lucerne as a fibre source to the rapid rate of digestion and available mineral component.

The results of the present study indicated that LH in finishing diets of lambs that contained high concentrate levels resulted in better overall nutrient availability compared with alternative fibre sources. Therefore, complete replacement of LH with SH, ET, or MS would probably result in a lower dietary energy 
concentration when diets are balanced based on NDF. Future studies should investigate whether the differences in digestibility of alternative fibre sources affect the performance of finisher lambs, but should consider the cost of gain and should determine the effect of replacing graded levels of lucerne. Although long-term matrix values and grading systems were used to predict the nutrient composition of these fibres sources, the quality of the fibre sources should be analysed before experimental diets are formulated for research.

\section{Acknowledgements}

The researchers express their sincere appreciation and gratitude to Oranje Rivier Voere, Dynamic Feeds and the Directorate for Research and Development (University of the Free State) for their financial support.

\section{Authors' Contributions}

JFM and OBE designed the experiment and carried out the research trial. MDF completed the statistical analyses. JFM, OBE and GCJ structured the scientific content and drafted the manuscript. AH \& AL assisted with the experimental design and research trial, while all authors provided editorial suggestions and approved the final manuscript.

\section{Conflict of Interest Declaration}

The authors declare that there is no conflict of interest.

\section{References}

Araujo, R.C., Pires, A.V., Susin, I., Mendes, C.Q., Rodrigues, G.H., Packer, I.U. \& Eastridge, M.L., 2008a. Milk yield, milk composition, eating behaviour and lamb performance of ewes fed diets containing soybean hulls replacing coastcross (Cynodon species) hay. J. Anim. Sci. 86, 3511-3521. DOI:10.2527/jas.2008-0940

Araujo, R.C., Pires, A.V., Susin, I., Urano, F.S., Mendes, C.Q., Rodrigues, G.H. \& Packer, I.U., 2008b. Apparent digestibility of diets with combinations of soybean hulls and coastcross (Cynodon sp.) hay offered to ram lambs. Sci. Agric. (Piracicaba, Braz.) 65(6), 581-588. http://dx.doi.org/10.1590/S0103-90162008000600003

AOAC, 2000. Official methods of analysis of AOAC International. 17th ed. Volume 1. Edited by W. Horwitz. AOAC International, Gaithersburg, Maryland, USA.

Ball, D.M., Collins, M., Lacefield, G.D., Martin, N.P., Mertens, D.A., Olson, K.E., Putnam, D.H., Undersander, D.J. \& Wolf, M.W., 2001. Understanding forage quality. American Farm Bureau Federation Publication 1-01, Park Ridge, IL.

Bampidis, V A. \& Robinson, P.H., 2006. Citrus by-products as ruminant feeds: A review. Anim. Feed Sci. and Technol. 128, 175-217. https://doi.org/10.1016/j.anifeedsci.2005.12.002

Cherney, D.J.R., Cherney, J.H. \& Chase, L.E., 2004. Lactation performance of Holstein cows fed fescue orchard grass or alfalfa silage. J. Dairy Sci. 87, 2268-2276. https://doi.org/10.3168/jds.S0022-0302(04)70047-8

Cunningham, K.D., Cecava, M.J. \& Johnson, T.R. 1993. Nutrient digestion, nitrogen and amino acid flows in lactating cows fed soybean hulls in place of forage or concentrate. J. Dairy Sci. 76, 3523-3535.

Decruyenaere, V., Buldgen, A. \& Stilmant, D., 2009. Factors affecting intake by grazing ruminants and related quantification methods: a review. Biotechnol. Agron. Soc. Environ. 13(4), 559-573.

Dryden, G.M., 2008. Animal nutrition science. CABI, Wallingford, UK. Pp. 47.

Flores-Mar, J., Zinn, R.A. \& Salinas-Chavira, J., 2018. Influence of forage NDF level and source in growing-finishing diets on growth performance of feedlot lambs. Acta Agriculturae Scandinavica. 67(3-4), 134-138. https://dx.doi.org/10.1080/09064702.2018.1469663

Harper, K.J. \& McNeill, D.M., 2015. The role of iNDF in the regulation of feed intake and the importance of its assessment in subtropical ruminant systems. Agriculture 5, 778-790. DOI: 10.3390/agriculture5030778

Ipharraguerre I.R. \& Clark, J.H., 2003. Soyhulls as an alternative feed for lactating dairy cows: A review. J. Dairy Sci. 86, 1052-1073. https://doi.org/10.3168/jds.S0022-0302(03)73689-3

Jabbar, M.A. \& Anjum, M.I., 2008. Effect of diets with different forage to concentrate ratio for fattening Lohi lambs. Pakistan Vet. J. 28(3), 150-152.

Jeon, S., Jeong, S., Lee, M., Seo, J., Kam, D.K., Kim, J.H., Park, J. \& Seo, S., 2019. Effects of reducing inclusion rate of roughages by changing roughage sources and concentrate types on intake, growth, rumen fermentation characteristics, and blood parameters of Hanwoo growing cattle (Bos taurus coreanae). AJAS 32(11), 1705-1714. https://doi.org/10.5713/ajas.19.0269

Jung, H.G. \& Allen, M.S. 1995. Characteristics of plant cell walls affecting intake and digestibility of forages by ruminants. J. Anim. Sci. 73, 2774-2790. Https://Doi.Org/10.2527/1995.7392774x

Lopes, L., Carvalho, F., Cabral, A.M.D., Batista, Â.M., Camargo, K.S., Silva, J.R.C., Ferreira, J.C.S., Neto, J.D. \& Silva, J., 2017. Replacement of tifton hay with alfalfa hay in diets containing spineless cactus (Nopalea cochenillifera Salm-Dyck) for dairy goats. Small Rumin. Res. 156, 7-11. https://doi.org/10.1016/j.smallrumres.2017.08.006

Martin, N.P. \& Mertens, D.R., 2005. Reinventing alfalfa for dairy cattle and novel uses. Proceedings, 35th California Alfalfa and Forage Symposium, Visalia, California. Pp 299-311.

McDonald, P., Edwards, R.A., Greenhalgh, J.F.D., Morgan, C.A., Sinclair, L.A. \& Wilkinson, R.G., 2011 (7th ed.). Animal nutrition. Prentice Hall. Pp. 291; 468-473.

Moore, K.J. \& Jung, H.J., 2001. Lignin and fiber digestion. Lignin and fiber digestion. J. Range. Manage. 54(4), 420-430. DOI: 10.2458/azu_jrm_v54i4_moore 
Mulvenna, C.C., Wilson, R.P., Marks, N.J., Maule, A.G. \& Scantlebury, D.M. 2018. The ability of magnetic field sensors to monitor feeding in three domestic herbivores. PeerJ. 6, e5489. https://doi.org/10.7717/peerj.5489

National Research Council (NRC), 2007. Nutrient requirements of small ruminants: Sheep, goats, cervids, and New World camelids. National Academies Press, Washington, USA.

Paulson, J., Jung, H., Raeth-Knight, M. \& Li, N.J., 2008. Grass vs. legume forages for dairy cattle. Proceedings of the 69th Minnesota Nutrition Conference, Owatonna, Minnesota, USA, 16-17 September 2008. Pp. 119-133.

Poore, M.H., Moore, J.A., Swingle, R.S., Eck, T.P. \& Brown, W.H. 1991. Wheat straw or alfalfa hay in diets with $30 \%$ neutral detergent fiber for lactating Holstein cows. J. Dairy Sci. 74, 3152-3159. https://doi.org/10.3168/jds.S00220302(91)78500-7

Saylor, B.A., Min, D.H. \& Bradford, B.J., 2018. Productivity of lactating dairy cows fed diets with teff hay as the sole forage. J. Dairy Sci. 101, 5987-5990. https://doi.org/10.3168/jds.2017-14118

Scholtz, G.D.J., Van der Merwe, H.J. \& Tylutki, T.P., 2009. The nutritive value of South African Medicago sativa L. hay. S. Afr. J. Anim. Sci. 39(S1), 179-182. DOI: 10.4314/sajas.v40i5.65332

Shapiro, S.S. \& Wilk, M.B. 1965. An analysis of variance test for normality (complete samples). Biometrika 52(3-4), 591611.

Shivambu, V.N., Hoon, J.H., Snyman, M.A. \& King, B.R., 2011. Effect of energy level in lucerne (Medicago sativa) haybased finishing diets on carcass characteristics of Merino lambs. Grootfontein Agric. 11(2), 55-62.

Soto-Navarro, S.A., Goetsch, A.L., Sahlu, T., Puchala, R. \& Dawson, L.J., 2003. Effects of ruminally degraded nitrogen source and level in a high concentrate diet on site of digestion in yearling Boer $\times$ Spanish wether goats. Small Rumin. Res. 50, 117-128. DOI: 10.1016/S0921-4488(03)00120-2

Sun, L., Yin, Q., Gentu, G., Xue, Y., Hou, M., Liu, L. \& Jia, Y., 2017. Feeding forage mixtures of alfalfa hay and maize stover optimizes growth performance and carcass characteristics of lambs. Anim. Sci. J. 89(2), 359-366. DOI: 10.1111/asj.12928

Tedeschi, L.O., Molle, G., Menendez, H.M., Cannas, A. \& Fonseca, M.A., 2019. The assessment of supplementation requirements of grazing ruminants using nutrition models. Transl. Anim. Sci. 2019(3), 812-828. DOI: 10.1093/tas/txy140

Van Soest, P.J., Robertson, J.B. \& Lewis, B. 1991. Methods for dietary fiber, neutral detergent fiber, and nonstarch polysaccharides in relation to animal nutrition. J. Dairy Sci. 74, 3583-3597. https://doi.org/10.3168/jds.S00220302(91)78551-2 